\title{
Faecal culturable microbiota, growth and clinical parameters of calves supplemented with lactic acid bacteria and lactose prior and during experimental infection with Salmonella Dublin DSPV 595T
}

\author{
Microbiota cultivable fecal, crecimiento y parámetros clínicos de terneros suplementados con \\ bacterias ácido lácticas y lactosa previo y durante una infección experimental con Salmonella \\ Dublin DSPV 595T
}

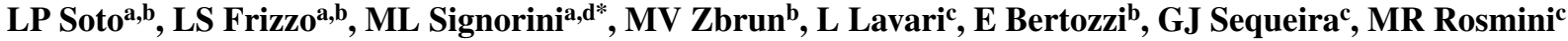 \\ ${ }^{a}$ Consejo Nacional de Investigaciones Científicas y Tecnológicas (CONICET), \\ bDepartamento de Salud Pública, Facultad de Ciencias Veterinarias, Universidad Nacional del Litoral, Esperanza, Provincia de Santa \\ Fe, Argentina. \\ 'Universidad Católica de Córdoba, Facultad de Ciencias Agrarias, Córdoba, Provincia de Córdoba, Argentina. \\ dinstituto Nacional de Tecnología Agropecuaria EEA Rafaela, Ruta 34 km 227 (CP 2300), Rafaela, Provincia de Santa Fe, \\ Argentina.
}

\section{RESUMEN}

\begin{abstract}
El objetivo de este trabajo fue evaluar el efecto del inóculo probiótico + lactosa sobre el peso, la microbiota intestinal, la morbilidad y la mortalidad de terneros jóvenes desafiados con Salmonella Dublin DSPV 595T. Se utilizaron 24 terneros divididos en un grupo control (GC) y un grupo probiótico (GP). Al GP se le administró $100 \mathrm{~g}$ lactosa.ternero ${ }^{-1} \cdot \mathrm{d}^{-1}$ y $10^{10}$ UFC.ternero-1. $\mathrm{d}^{-1}$ de cada cepa de un inóculo probiótico compuesto por Lactobacillus casei DSPV318T, Lactobacillus salivarius DSPV315T y Pediococcus acidilactici DSPV006T a lo largo de todo el experimento. El patógeno fue administrado el día 11 del experimento, en una dosis oral de $10^{9} \mathrm{UFC}_{\text {animal }}{ }^{-1}$. Las poblaciones de Lactobacillus y levaduras fueron modificadas en el GP a causa de la administración del inóculo + lactosa. La severidad de la diarrea fue menor en el GP. No se encontraron diferencias en el resto de los signos clínicos, el peso vivo y la mortalidad entre los dos grupos analizados. En este estudio, la administración periódica de un inóculo probiótico de origen bovino y lactosa, favoreció el establecimiento de una microbiota intestinal más estable y balanceada, aun durante una infección con Salmonella. El modelo de infección aguda le dio la oportunidad al probiótico de ejercer su efecto benéfico sobre la severidad de la diarrea. Sin embargo, para futuros estudios se recomienda el uso de dosis menores de $S$. Dublin DSPV 595T, para generar un modelo menos severo para evaluar si el inóculo es capaz de ejercer una respuesta diferente en los signos clínicos de terneros jóvenes.
\end{abstract}

Palabras clave: terneros, probióticos, Salmonella, lactosa.

\section{SUMMARY}

The aim of this study was to evaluate the probiotic inoculum + lactose effect on weight, intestinal culturable microbiota, morbidity and mortality of young calves challenged with Salmonella Dublin DSPV 595T. Twenty eight calves were used, divided in control group (CG) and probiotic group (PG). The PG was provided with $100 \mathrm{~g}$ lactose.calf ${ }^{-1} \cdot \mathrm{d}^{-1}$ and $10^{10} \mathrm{CFU}$.calf ${ }^{-1} \cdot \mathrm{d}^{-1}$ of each strain of a probiotic inoculum composed of Lactobacillus casei $\mathrm{DSPV}$ 318T, Lactobacillus salivarius DSPV 315T and Pediococcus acidilactici DSPV 006T throughout the experiment. The pathogen was administered on day 11 of the experiment, at an oral dose of $10^{9} \mathrm{CFU}$. calf $^{-1}$. Lactobacillus and yeast populations were modified in PG because of inoculum + lactose administration. Severity of diarrhea was lower in PG. No differences were found on the rest of clinical sings, live weight and mortality between the two groups analysed. The periodic administration of a probiotic inoculum of bovine origin and lactose, favoured the establishment of a more stable and balanced intestinal culturable microbiota, even during an infection with Salmonella. The generated model of acute infection gave opportunity to the probiotic to exert its beneficial effect on severity of diarrhea. However, the use of lower doses of $S$. Dublin DSPV 595T are recommended for future studies, to generate less severe model in order to evaluate if the inoculum is able to exert a differential response in the clinical symptoms of young calves.

Keywords: calves, probiotics, Salmonella, lactose.

\section{INTRODUCTION}

The balance of the intestinal microbiota is of vital importance in the host nutritional status and is of particular

Accepted: 20.08.2015.

* P. Kreder 2805. (CP S3080HOF) Esperanza, Santa Fe, Argentina; marcelo.signorini@gmail.com interest in farm animals that are raised in intensive systems (Rosmini et al 2004). The balance of the intestinal ecosystem can be altered in intensive farming systems due to separation from their mothers, feeding with milk replacers and the subsequent elimination of the benefits of cow's milk, inadequate colostrum intake, stressful situations, and use of antibiotics (Signorini et al 2012; Bayatkouhsar et al 2013). This imbalance leaves the animals in a state 
of increased susceptibility to infections. One of the most common culturable bacterial pathogen found in calves is Salmonella, being Salmonella enterica serotype Dublin the predominant type (Paulin et al 2002).

Probiotics are "live micro-organisms which, when administered in adequate amounts, confer a health benefit on the host" (FAO/WHO 2001). The periodic administration of a probiotic inoculum of bovine origin seems to favour the establishment of a more stable and balanced intestinal microbiota, thus improving the health of calves (Abe et al 1995). Lactic acid bacteria (LAB) with probiotic properties has been considered as possibly responsible for controlling the effects of Salmonella spp. (Fayol-Messaoudi et al 2007, Rishi et al 2009, Castillo et al 2012). The use of a probiotic inoculum could control the action of this pathogen by improving the intestinal microbial balance. The aim of this study was to evaluate the effect of administration of a probiotic inoculum and lactose on weight, culturable intestinal microbiota, morbidity and mortality of young calves challenged with Salmonella Dublin DSPV 595T.

\section{MATERIAL AND METHODS}

ANIMALS

A total of 28 calves Holstein (Bos taurus) with a mean age of 5 days of life were used in the experiment, divided into two experimental groups of 15 animals in the $\mathrm{CG}$ and 13 animals in the PG. All animals were fed with starter supplied without drugs and water ad libitum and with a milk replacer $\left(41 . \mathrm{d}^{-1}\right)$, rationed directly into the feeder twice a day. Spray-dried lactose was also provided to the PG (50 $\mathrm{g}$ in each administration) together with the milk replacer (Frizzo et al 2011 ${ }^{\mathrm{a}}$ ), and $150 \mathrm{ml}$ of probiotic inoculum in the afternoon delivery of milk replacer. The calves were evaluated for $27 \mathrm{~d}$. Animals care was provided following the Guidelines for the care and use of animals in research and teaching (FASS 1998).

\section{MICROORGANISMS}

The inoculum used consisted of: Lactobacillus casei DSPV 318T, Lactobacillus salivarius DSPV 315T and Pediococcus acidilactici DSPV 006T. Their accession numbers in GenBank are: FJ787305, FJ787306 and FJ787307, respectively. The pathogen used was $S$. Dublin DSPV 595T, whose accession number in GenBank is FJ997268.

\section{SELECTION OF ANTIBIOTIC-RESISTANT MUTANTS}

In order to monitor the inoculated strains, they were marked by antibiotic resistance for distinguishing them from strains present in the gut (Demecková et al 2002). The antibiotic resistance of LAB of the inoculum was obtained by successive cultures in Lactobacillus Anaerobic MRS with vancomycin and bromocresol (LAMVAB) medium
(Hartemink et al 1997) from low concentrations up to a concentration of $10 \mu \mathrm{g} . \mathrm{ml}^{-1}$ of rifampicin (Demecková et al 2002). A similar procedure was used with the strain $S$. Dublin DSPV 595T using xylose, lysine, desoxicolate (XLD) medium and the antibiotics novobiocin $(50 \mu \mathrm{g} /$ $\mathrm{ml})$ and nalidixic acid $(10 \mu \mathrm{g} / \mathrm{ml})\left(\mathrm{XLD}_{\text {nov/nal }}\right)($ Oyofo $e t$ al 1989).

\section{PREPARATION AND ADMINISTRATION OF LAB INOCULUM}

The bacteria were multiplied in skim milk (100 g. $\left.\mathrm{L}^{-1}\right)$ supplemented with casein hydrolysate $\left(50 \mathrm{ml} . \mathrm{L}^{-1}\right)$ for $18-20 \mathrm{~h}$ at $37{ }^{\circ} \mathrm{C}$ unstirred. The culture was dispersed into containers and frozen at $-20{ }^{\circ} \mathrm{C}$ until use in artificial rearing of calves, which consisted of a total dose of $10^{10}$ CFU.calf ${ }^{-1} \cdot \mathrm{d}^{-1}$ of each strain (Soto et al 2009, Frizzo et al 2012). This inoculum was administered to the calves of the probiotic group (PG) during the 27 days of the experiment. The control group (CG) was inoculated in the same way but with $150 \mathrm{ml}$ of skim milk $\left(100\right.$ g.L $\left.{ }^{-1}\right)$, which served as a placebo.

\section{PATHOGEN INOCULATION}

The $S$. Dublin DSPV 595T strain, cultivated in brain heart infusion (BHI) broth for $18 \mathrm{~h}$ at $37^{\circ} \mathrm{C}$, was administered together with the milk replacer, on day 11 of the experiment to all calves of the two experimental groups (CG and PG). To establish the strain concentration, tenfold dilutions were made from a culture. In this culture and its dilutions, absorbance was determined at $560 \mathrm{~nm}$ and, simultaneously, counts on plates were performed. Regression analysis was performed with both parameters. Subsequently, to quantify the amount provided we used the equation $\mathrm{y}=0.4735 \ln (\mathrm{x})+8.2162$, where $\mathrm{y}$ corresponds to $\log _{10}$ CFU.ml ${ }^{-1}$ and the variable $x$ measures the absorbance of the culture. The pathogen was given at a dose of $10^{9}$ CFU.animal $^{-1(1)}$.

\section{EXPERIMENTAL DESIGN}

Live weight data were recorded at the beginning of the experiment, prior to pathogen inoculation and at the end of the experiment (day 1, 10 and 27).

The health status of the animals was determined daily by the following clinical indicators: body temperature, dehydration level, frequency of diarrhoea by a macroscopic analysis of faeces, severity of diarrhoea, presence or absence of ocular discharge, state of the mucosa, cold nose, cold extremities, weakness in the hindquarters and difficulty in standing up. The temperature was determined as normal up to $40.5^{\circ} \mathrm{C}$. The level of dehydration was determined by skinfold time as suggested by Blood et al (1986). Faeces were macroscopically analyzed according

$\overline{1 \quad \text { Data not published }}$ 
to the scores proposed by Meyer et al (2001) (Table 1). The indicators for severity of diarrhoea, eye discharge, state of the mucosa and difficulty in standing up are described in table 1 . Given these parameters, morbidity was calculated based on the proportion of animals with abnormal appearance in each group.

\section{RECOVERY OF LAB INOCULUM, TOTAL LACTOBACILLUS AND OTHER CULTURABLE POPULATIONS FROM THE INTESTINAL MICROBIOTA}

Faecal samples (approximately $5 \mathrm{~g}$ ) were obtained from three calves of each group by rectal massage on days 1, 5, 10 and 27 of the experiment, and then weighed, diluted $1.100^{-1}$ in Ringer $1 / 4$ solution and homogenised on a magnetic stirrer according to Frizzo et al $\left(2011^{\mathrm{b}}\right)$. Serial dilutions of each sample were pour-plated with different media for the count of the population detailed in table 2 .

\section{DETECTION OF SALMONELLA DUBLIN DSPV 595T IN FAECES}

The faecal samples were collected from all experimental animals at the beginning of the experiment and on days 15 and 27 by rectal massage. Faeces were cultured either in selenite cystine broth for $12 \mathrm{~h}$ at $42{ }^{\circ} \mathrm{C}$ and in Rappaport Vassiliadis broth for $18 \mathrm{~h}$ at $42^{\circ} \mathrm{C}(1 \mathrm{~g}$ and $0.1 \mathrm{~g}$ respectively). After incubation, the culture was inoculated in $\mathrm{XLD}_{\text {nov/nal }}$ agar plates, which were incubated at $37^{\circ} \mathrm{C}$ for $24 \mathrm{~h}$. The finding of typical colonies with positive agglutination test with a polyclonal antibody (OS-A and OS-B, A.N.L.I.S Dr. Carlos G. Malbrán) showed a positive result for Salmonella Dublin.

\section{STATISTICAL ANALYSIS}

The effect of probiotic administration on weight, temperature, and microbial counts was analysed in a factorial ANOVA (treatment $x$ time) and Duncan`s test. Ordinal variables (clinical indicators: macroscopic analysis of faeces; severity of diarrhoea; eye discharge; state of the mucosa; difficulty in standing up) were analised using the Mann-Whitney test. Dichotomic variables (clinical indicators: cold nose; cold extremities; weakness in hind quarters) were performed using Chi-squared test. A Kaplan-Meier survival analysis (using Breslow test) was performed to evaluate the effect of probiotic supplementation on mortality as consequence of Salmonella infection. For these analyses, SPSS 11.0 for Windows software was used with $\mathrm{P}<0.05$ representing a significant difference between means.

Table 1. Severity level for each clinical indicator.

Nivel de severidad para cada indicador clínico.

\begin{tabular}{|c|c|c|c|c|}
\hline \multirow{2}{*}{ Clinical indicators } & \multicolumn{4}{|c|}{ Level } \\
\hline & 1 & 2 & 3 & 4 \\
\hline $\begin{array}{l}\text { Macroscopic analysis } \\
\text { of faeces }\end{array}$ & $\begin{array}{l}\text { Normal: firm stools, but } \\
\text { not hard, their original } \\
\text { shape is distorted slightly } \\
\text { when it falls and sits on } \\
\text { the floor }\end{array}$ & $\begin{array}{l}\text { Soft: shapeless, when they } \\
\text { fall they are deposited } \\
\text { in mounds and spread } \\
\text { slightly }\end{array}$ & $\begin{array}{l}\text { Fluid: they disperse rapid- } \\
\text { ly in sheets of } 6 \mathrm{~mm} \text { deep }\end{array}$ & $\begin{array}{l}\text { Watery: liquid consistency } \\
\text { (diarrhoea) }\end{array}$ \\
\hline Severity of diarrhoea & mucosa & bloody & egg yolk & fibrinous \\
\hline Eye discharge & serous & purulent & fibrinous & - \\
\hline State of the mucosa & normal & pale-hyperemic & with petechiae & icteric \\
\hline $\begin{array}{l}\text { Difficulty in } \\
\text { standing up }\end{array}$ & normal & slow & with help & prostrated \\
\hline
\end{tabular}

Table 2. Microbial population studied, media and culture conditions used.

Poblaciones microbianas estudiadas, medios y condiciones de cultivo utilizadas.

\begin{tabular}{lll}
\hline Microorganisms & \multicolumn{1}{c}{ Media } & Culture conditions \\
\hline Lactobacillus spp. & LAMVAB & Anaerobiosis, $48 \mathrm{~h}, 37^{\circ} \mathrm{C}$ \\
Inoculum & LAMVAB $_{\text {rif }}$ & Anaerobiosis, $48 \mathrm{~h}, 37^{\circ} \mathrm{C}$ \\
Coliforms & Violet Red Bile Lactose (VRBL) & Aerobiosis, $24 \mathrm{~h}, 37^{\circ} \mathrm{C}$ \\
Yeast & Fungi and yeasts $(\mathrm{F} \mathrm{\&} \mathrm{Y)} \mathrm{modified} *$ & Aerobiosis, $48 \mathrm{~h}, 37^{\circ} \mathrm{C}$ \\
Enterococci & Slanetz and Bartley $(\mathrm{S} \& \mathrm{~B})$ & Aerobiosis, $24 \mathrm{~h}, 37^{\circ} \mathrm{C}$ \\
\hline
\end{tabular}

$*$ With the addition of $2 \%$ dextrose and $0.5 \%$ pluripeptone. 


\section{RESULTS AND DISCUSSION}

At the beginning of the experiment the weight of calves was similar for both groups (41.8 kg PG and 40.9 $\mathrm{kg} \mathrm{CG}, \mathrm{P}>0.05$ ) and no differences were found between the groups on any of the next evaluated days. During the first 10 days of the experiment, the calves from both groups lost weight (CG animals lost $1 \mathrm{~kg}$ whereas PG ones lost $0.1 \mathrm{~kg}$ in average), which is considered normal during the first weeks of life for calves and may be due to transport stress (Adams et al 2008). On day 27, animals

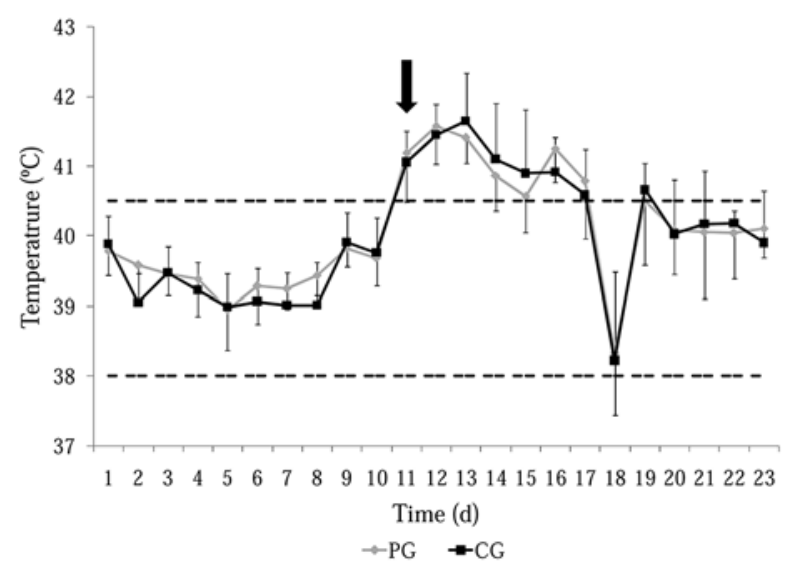

Figure 1. Average daily rectal temperature in control group (CG) and probiotic group (PG). The arrow indicates the time of inoculation with Salmonella Dublin DSPV 595T. The dotted lines indicate the range of normal values of rectal temperature in cattle.

Promedio diario de temperatura rectal en el grupo control (CG) y el grupo probiótico (PG). La flecha indica el momento de la inoculación con Salmonella Dublin DSPV 595T. La línea de puntos indica el rango de valores normales de la temperatura rectal en terneros.

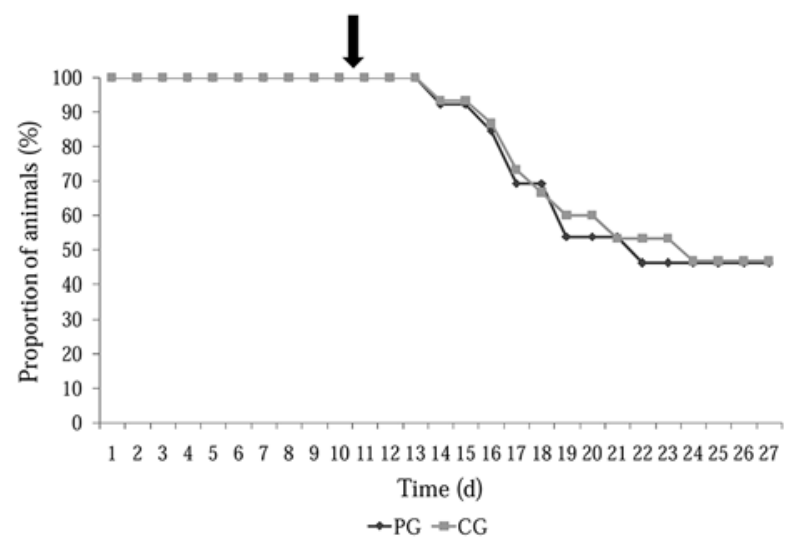

Figure 2. Percentage of live animals of control group (CG) and probiotic group (PG) during the experiment. The arrow indicates the time of inoculation with Salmonella Dublin DSPV 595T.

Porcentaje de animales vivos del grupo control (CG) y grupo probiótico (PG) durante el experimento. La flecha indica el momento de la inoculación con Salmonella Dublin DSPV 595T. that survived had a weight gain of $7.3 \mathrm{~kg}$ for PG and of $3.8 \mathrm{~kg}$ for $\mathrm{CG}$ as compared to the start of the experiment.

Prior to the beginning of the experiment the animals were free of the pathogen. On day 15 of the experiment, which corresponds to day 4 post-infection, Salmonella was detected in faeces of both groups (60\% of animals of GC and $33 \%$ of animals of PG) and on day 27 , only a small percentage of the PG (16\%) was positive to Salmonella. There were no differences $(\mathrm{P}>0.05)$ in the presence/absence of Salmonella between groups for any of the times evaluated. Salmonella detection not always is an indicator of the real presence of this pathogen, because bacteria are not excreted continuously. This was evident when all animals manifested typical signs of illness (day 15), but not all of them were positive to Salmonella detection. Similarly, it is expected that even after the animals are recovered, the pathogen is found in the stool, because excretion of the pathogen can remain in the surviving animals for months and even years (Klee 2005).

Differences ( $\mathrm{P}=0.009)$ in the Lactobacillus count in faeces between the two groups were found at day 10 of the experiment. At this moment, the CG counts decreased showing 2.19 Log CFU.g ${ }^{-1}$ less than those of the PG. On day 5 of the start of the administration of the probiotic, most of the faecal Lactobacillus recovered were the strains belonging to the inoculum. This relationship was kept during the following sampling points (figure 3). In the pre infection period Lactobacillus population stabilised in the $\mathrm{PG}$ at normal concentration reaching the level between $10^{7}$ and $10^{8}$ CFU.g-1 suggested by Anadón et al (2006). This population decreases in calves in an artificial rearing system, fed with milk replacer containing antibiotics (Ozawa et al 1983). In this work, Lactobacillus population decreased in $\mathrm{CG}$ even without antibiotic supplementation, showing the effects caused on this bacterial population by artificial rearing system. On day 27 (16 days after infection with $S$. Dublin DSPV 595T) counts of Lactobacillus of both groups decreased, being more pronounced $(\mathrm{P}=0.042)$ in the CG, which reached 1 Log CFU.g ${ }^{-1}$, i.e. 5 Log CFU.g ${ }^{-1}$ less than the PG. Both Coliforms as Enterococci were not affected by the probiotic treatment neither before nor after the infection. Coliforms population remained constant over time, except on day 5 , when it was increased $(\mathrm{P}=0.01)$ for both groups (figure 3), which may have been due to the stress experienced by the relocation of calves, which was reflected in the decrease in weight. This condition was reversed on day 10 , when animals were already adapted to such conditions. Using the values of Lactobacillus and coliforms populations the relationship between them was analysed. This Lactobacillus/coliforms relationship was higher for the $\mathrm{PG}(\mathrm{P}=0.011)$ from day 10 of the experiment and a relationship of more than 1 for the PG and less than 1 for the CG, both before and after the infection (figure 4). This index Lactobacillus/coliforms has been related to the presence/absence of diarrhea by Abu-Tarboush et al (1996) propose that animals with diarrhoea have a rate lower 

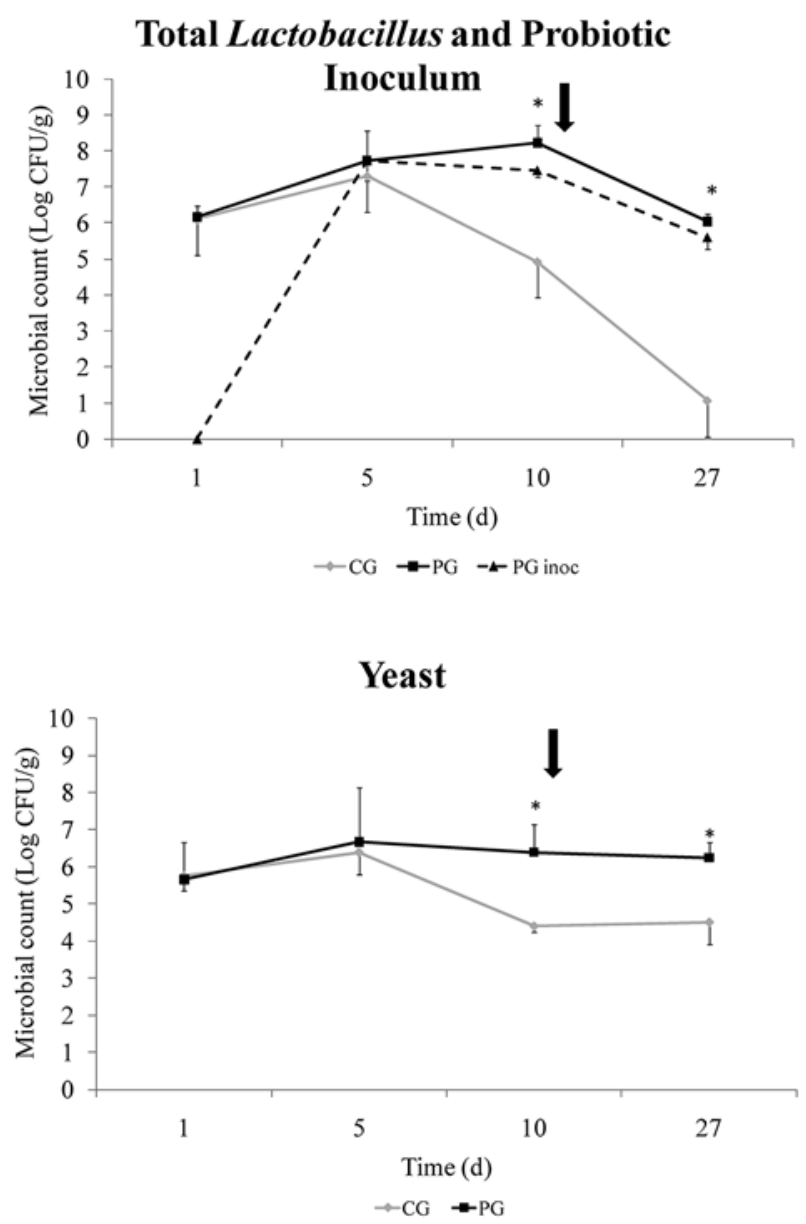

\section{Coliforms}

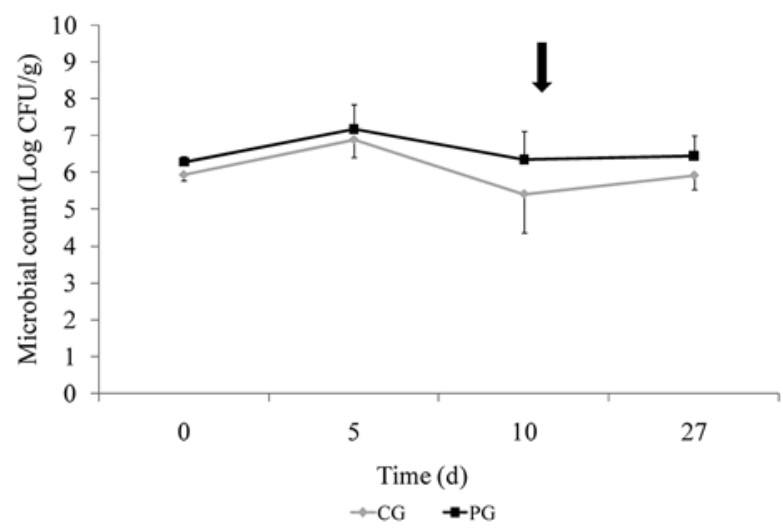

Enterococci

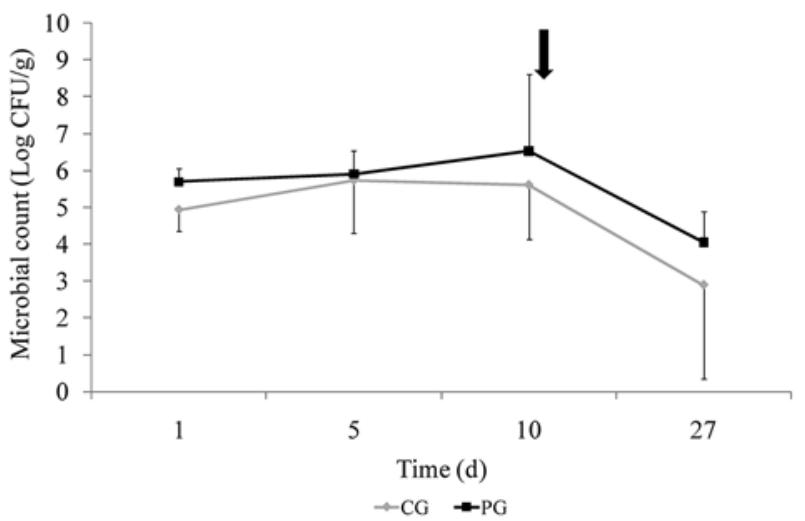

Figure 3. Counting of the populations of Lactobacillus, probiotic inoculum, coliforms, enterococci and yeast on days $1,5,10$ and 27 of the experiment in control group (CG) and probiotic group (PG).* Means significant differences between CG and PG for the same time. PGinoc represents the count of bacteria belonging to the inoculum in the PG. The arrow indicates the time of inoculation with Salmonella Dublin DSPV 595T.

Recuento de poblaciones de Lactobacillus, inóculo probiótico, coliformes, enterococos y levaduras los días 1, 5, 10 y 27 del experimento en el grupo control (CG) y grupo probiótico (PG). *Significa diferencias significativas entre CG y PG en el mismo momento. PGinoc representa el recuento de bacterias que pertenecen al inóculo en el PG. La flecha indica el momento de la inoculación con Salmonella Dublin DSPV 595T.

than 1 , while healthy ones have an index greater than 1 . In this study the group that showed an index lower than 1 had higher severity of diarrhoea than the group with a rate greater than 1, suggesting that it might be a correlation between these parameters. Yeast population was affected by the inoculum's administration presenting differences of more than 1.5 Log CFU.ml ${ }^{-1}$ compared to the CG on days $10(\mathrm{P}=0.039)$ and $27(\mathrm{P}=0.014)$. The $\mathrm{PG}$ counts remained stable throughout the experiment, whereas the CG decreased $(\mathrm{P}=0.003$ ) from day 10 (figure 3 ). It had been reported an antagonistic effect of the probiotic on the yeast population by Ozawa et al (1983). Instead, our results indicate that the administration of inoculum + lactose remained constant yeast counts in faeces of $\mathrm{PG}$, as opposed to the $\mathrm{CG}$ in which this population was diminished over time. For the above might suppose that the administration of probiotics have a synergistic or antagonistic effect depending on the composition of the inoculums. On the other hand, should be clarified that in this work the effect of administration of LAB was studied on some populations and can not excluded that other unstudied populations have been modified by the addition of inoculum. Cultural methods used in this work are useful for the quantification of specific populations. To determine a change in any of the predominant populations in the complex intestinal microbiota is suggested to use rRNA-based analysis (Mayer et al 2012, Uyeno et al 2010).

All the clinical signs evaluated showed normal values during the first 10 days of the experiment in the pre-infection stage (data not shown), showing the good health of the calves before the Salmonella's inoculation. In the post-infection period, all the animals showed at least one sign of disease, although with different frequencies of occurrence, being more frequent during the first 10 days 


\section{Lactobacillus/Coliforms}

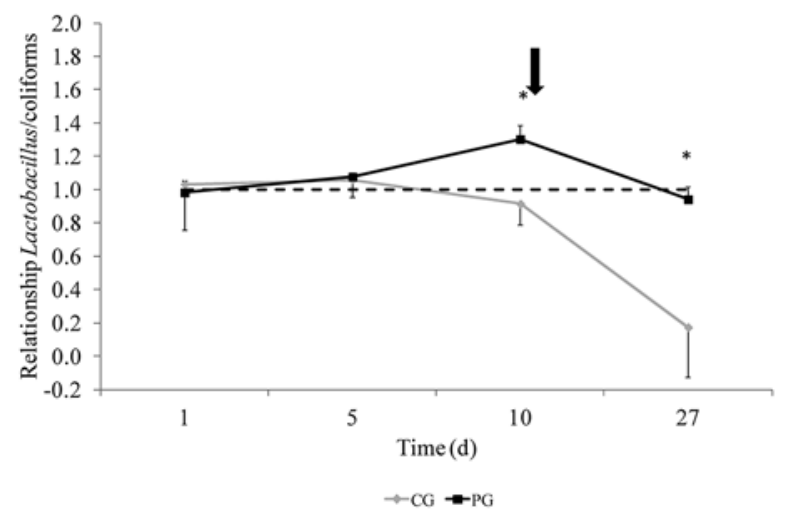

Figure 4. Lactobacillus relationship.Coliforms ${ }^{-1}$ in the control group (CG) and probiotic group (PG) during the experiment. * Means significant differences between CG and PG for the same time.

Relación Lactobacillus.Coliformes ${ }^{-1}$ en el grupo control (CG) y grupo probiótico (PG) durante el experimento. *Significa que existen diferencias significativas entre el CG y PG en el mismo momento.

after inoculation of Salmonella. The faecal consistency was one of the clinical signs that clearly showed infection. During the pre-infection stage, most of the calves had a faecal consistency of 2 . After the administration of $S$. Dublin DSPV 595T most of the calves had a faecal consistency of 4 (diarrhoea). There were no significant differences between both groups in this parameter. For the indicator severity of diarrhoea was found that the number of animals with more severe diarrhoea was higher in the CG than in the PG (table 3). In the post-infection phase, half of the calves were normal and the other half had a level 2 in the state of the mucosa (pale or hyperemic) (table 3). These characteristic symptoms were seen during the first 10 days of infection. From day 10 post-infection, the number of calves that expressed symptoms decreased gradually and there were no differences between CG and PG. Very few animals showed abnormal levels as regards eye discharge and difficulty in standing up. These two parameters showed no differences between the two groups (table 3). From day 12 of the experiment and during the first 10 days post-infection, presence of cold extremities, cold nose and weakness in the hind quarters in high frequency were observed. After this period, the frequency of occurrence of such signs began to decrease. None of these three signs showed differences between both groups throughout the experiment (table 4). The degree of dehydration was assessed by measuring the skinfold time. This feature was normal during the pre-infection period. After inoculation of the pathogen, more than half of the animals showed a skinfold time between 2 and $4 \mathrm{~s}$, thus showing dehydration. No differences between both groups were found for these parameters. The same day that was administered $S$. Dublin DSPV 595T, the rectal temperature began to increase above $40.5^{\circ} \mathrm{C}$, thus showing infection. The peak temperature was observed on day 13 (forty eight $\mathrm{h}$ after administration of the pathogen) and then decreased gradually to normal values on day 20 (figure 1). Both groups of calves behaved in the same way. Affected animals with salmonellosis show high fever between 40.5 and $42{ }^{\circ} \mathrm{C}$ (Wray and Davies 2000), but the curves of temperature may vary according to the model used, because in general, Salmonella infections present a variety of clinical manifestations depending on age of the animal, serotype and pathogen dose (Sarwari et al., 2001). In this study, high fever became apparent soon after the administration of the pathogen, only 12 $\mathrm{h}$ post infection (figure 1) in contrast with other studies that observed a slower response, which led the animals to manifest fever among 24 and $72 \mathrm{~h}$ post infection (Paulin et al 2002, Silva et al 2010).

The animals began to die on day 14 of the experiment, three days after pathogen inoculation. The deaths were "in

Table 3. Proportion of animals (\%) that showed different severity levels for each clinical sign evaluated: faecal consistency, severity of diarrhoea, state of the mucosa, eye discharge and difficulty in standing up during the period after infection with $S$. Dublin DSPV $595 \mathrm{~T}$ for control group (CG) and probiotic group (PG).

Proporción de animales (\%) que presentaron diferentes niveles de severidad para cada signo clínico evaluado: consistencia fecal, severidad de la diarrea, estado de la mucosa, descarga ocular y dificultad en la incorporación durante el periodo post infección con $S$. Dublin DSPV 595T para el grupo control (CG) y el grupo probiótico (PG).

\begin{tabular}{|c|c|c|c|c|c|c|c|c|c|}
\hline & \multicolumn{8}{|c|}{ Experimental groups } & \multirow{4}{*}{$\mathrm{P}$} \\
\hline & \multicolumn{4}{|c|}{ PG } & \multicolumn{4}{|c|}{ CG } & \\
\hline & \multicolumn{4}{|c|}{ Severity level } & \multicolumn{4}{|c|}{ Severity level } & \\
\hline & 1 & 2 & 3 & 4 & 1 & 2 & 3 & 4 & \\
\hline Faecal consistency & 7.6 & 21.7 & 8.3 & 62.4 & 6.7 & 19.0 & 12.0 & 62.4 & 0.677 \\
\hline Severity of diarrhoea & 37.1 & 7.3 & 12.4 & 43.3 & 24.8 & 14.2 & 8.7 & 50.5 & 0.049 \\
\hline State of mucosa & 50.3 & 47.6 & 2.1 & 0.0 & 47.1 & 52.6 & 0.3 & 0.0 & 0.568 \\
\hline Eye discharge & 85.9 & 9.3 & 4.8 & - & 90.2 & 7.8 & 2.0 & - & 0.103 \\
\hline Difficulty in standing up & 80.3 & 10.7 & 6.2 & 2.8 & 84.7 & 5.5 & 6.1 & 3.8 & 0.214 \\
\hline
\end{tabular}


Table 4. Proportion of animals (\%) that showed presence of clinical signs (cold extremities, cold nose and weakness in hind quarters) after inoculation with the pathogen.

Proporción de animales (\%) que presentaron signos clínicos (extremidades frias, morro frío, debilidad en el tren posterior) después de la inoculación con el patógeno.

\begin{tabular}{lllll}
\hline & \multicolumn{2}{c}{ Experimental groups } & \multirow{2}{*}{$\mathrm{P}$} \\
\cline { 2 - 3 } & \multicolumn{2}{c}{$\mathrm{PG}^{*}$} & $\mathrm{CG}^{*}$ & \\
\hline Cold nose & 47.4 & 47.6 & 0.962 \\
Cold extremities & 46.8 & 46.9 & 0.812 \\
Weakness in hind quarters & 18.2 & 23.1 & 0.153 \\
\hline
\end{tabular}

*PG: probiotic group; CG: control group.

drip" ( 1 or 2 calves. $\mathrm{d}^{-1}$.group ${ }^{-1}$ ). Most deaths occurred during the first 10 days post-infection. Only three calves died after this period. The last calf died on day 24 of the experiment. In total, $53 \%$ of the animals in each group died following Salmonella challenge (figure 2). Most animals that survived after infection, proved to be in a stage of reversal of the disease. The experiment was closed $72 \mathrm{~h}$ after no more deaths were observed. Kaplan-Meier survival test was non-significant $(\mathrm{P}=0.904)$. Mortality accounted for half of the infected animals (figure 2) so we define this as the lethal dose $50\left(\mathrm{LD}_{50}\right)$. This is the first time this dose of strain $S$. Dublin DSPV 595T $\left(10^{9} \mathrm{CFU}\right.$. animal $^{-1}$ ) was given to generate a model of salmonellosis in calves, which was sufficient to induce the disease in all the animals tested, and the rapid clinical manifestation of the disease observed in this study shows that the model resulted in an acute infection in all animals. Although the dose used proved to be useful for building the model of the disease, the acute manifestation of the illness was not adequate to observe probiotic effects in some clinical signs (Frizzo et al 2012). The use of lower doses may be useful for development of symptomatic disease and evaluate the action of probiotic in this context. Therefore, for future studies are suggested to decrease the dose of the pathogen to levels that ensure the development of the disease in all individuals, and also would allow measure probiotic beneficial effects.

In this paper we propose a model of acute infection of Salmonella that has been useful to observe probiotics beneficial effects in the intestine. The daily administration of LAB inoculum + lactose supplementation favoured the establishment a stable amount of Lactobacillus and yeasts in faeces also before and during infection with $S$. Dublin DSPV 595T. The generated model of acute infection gave opportunity to the probiotic to exert its beneficial effect on severity of diarrhoea. However, for future studies use of lower doses of $S$. Dublin DSPV 595T are recommended, to generate less severe model to evaluate if the inoculum is able to exert a differential response in the clinical symptoms of young calves.

\section{ACKNOWLEDGEMENTS}

This study was financed by Universidad Nacional del Litoral, Universidad Católica de Córdoba and Asociación Cooperadoras Argentinas (ACA). L.S. Frizzo, L.P. Soto and M.L. Signorini are Researchers Career Members from Consejo Nacional de Investigaciones Científicas y Técnicas (CONICET, Argentina). M.V. Zbrun is doctoral fellow from CONICET (Argentina).

\section{REFERENCES}

Abe F, N Ishibashi, S Shimamura. 1995. Effect of administration of Bifidobacteria and lactic acid bacteria to newborn calves and piglets. J Dairy Sci 78, 2838-2846.

Abu-Tarboush H, M Al-Saiady, A Keir El-Din. 1996. Evaluation of diet containing Lactobacilli on performance, fecal coliform, and lactobacilli of dairy calves. Anim Feed Sci Technol 57, 39-49.

Adams MC, J Luo, D Rayward, S. King, R Gibson, GH Moghaddam. 2008. Selection of a novel direct-fed microbial to enhance weight gain in intensively reared calves. Anim Feed Sci Technol 145, 41-52.

Anadón A, MR Martinez-Larrañaga, M Aranzazu Martínez. 2006. Probiotics for animal nutrition in the European Union. Regulation and safety assessment. Regul Toxicol Pharmacol 45, 91-95.

Bayatkouhsar J, A Tahmasebi, A Naserian, R Mokarram, R Valizadeh. 2013. Effects of supplementation of lactic acid bacteria on growth performance, blood metabolites and fecal coliform and lactobacilli of young dairy calves. Anim. Feed Sci Technol 186, 1-11.

Blood DC, SA Henderson, OM Radostits. 1986. Medicina Veterinaria. $6^{\mathrm{a}}$ ed. Ed. Interamericana, México.

Castillo NA, A de Moreno de LeBlanc, CM Galdeano, G Perdigón. 2012. Comparative study of the protective capacity against Salmonella infection between probiotic and nonprobiotic lactobacilli. J Appl Microbiol 114, 861-876

Demecková V, D Kelly, AGP Coutts, PH Brooks, A Campbell. 2002. The effect of fermented liquid feeding on the faecal microbiology and colostrums quality of farrowing sows. Int J Food Microbiol 79, 85-97.

FAO/WHO. 2001. Evaluation of health and nutritional properties of probiotics in food including powder milk with live lactic acid bacteria. Expert consultation report: Córdoba, Argentina: Food and agriculture organization of the United Nations and World Health Organization, 1-4 October.

Fayol-Messaoudi D, MH Coconnier-Polter, V Lievin-Le Moal, F Atassi, CN Berger, AL Servin. 2007. The Lactobacillus plantarum strain ACA-DC287 isolated from a Greek cheese demonstrates antagonistic activity in vitro and in vivo against Salmonella enterica serovar Typhimurium. J Appl Microbiol 103, 657-665.

FASS (Federation of Animal Science Societies), 1998 Guide for the Care and Use of Agricultural Animals in Agricultural Research and Teaching. $1^{\text {st }}$ rev. ed. Federation of Animal Science Societies, Savoy, IL, USA, Pp 80-84.

Frizzo LS, LP Soto, MV Zbrun, E Bertozzi, GJ Sequeira, R Rodriguez Armesto, MR Rosmini. 2011 ${ }^{\mathrm{a}}$. Effect of lactic acid bacteria and lactose on growth performance and intestinal microbial balance of artificially reared calves. Livestock Sci 140, 246-252.

Frizzo LS, LP Soto, E Bertozzi, MV Zbrun, ML Signorini, G Sequeira, R Rodríguez Armesto, MR Rosmini. 2011 ${ }^{\mathrm{b}}$. Intestinal populations of Lactobacilli and coliforms after in vivo Salmonella dublin challenge and their relationship with microbial translocation in calves supplemented with lactic acid bacteria and lactose. Anim Feed Sci Technol 170, 12-20.

Frizzo LS, MV Zbrun, LP Soto, E Bertozzi, G Sequeira, LE Marti, ML Signorini, R Rodríguez Armesto, MR Rosmini. 2012. Pathogen translocation and histopathological lesions in an experimental model of Salmonella Dublin infection in calves supplemented with lactic acid bacteria and lactose. $J$ Vet Sci 13, 261-270. 
Hartemink R, VR Domenech, FM Rombouts, 1997. LAMVAB-A new selective medium for the isolation of lactobacilli from faeces. $J$ Microbiol Meth 29, 77-84.

Klee W. Enfermedades de los intestinos. 2005. En: Dirksen G, Gründer $\mathrm{H}$, Stöber M. Medicina interna y cirugía del bovino. $4^{\mathrm{a}}$ ed. InterMédica, Buenos Aires, Argentina, Pp 468-543.

Mayer M, A Abenthum, JM Matthes, D Kleeberger, MJ Ege, C Hölzel, J Bauer, K Schwaiger. 2012. Development and genetic influence of the rectal bacterial flora of newborn calves. Vet Microbiol 161, 179-185.

Meyer PM, A Vaz Pires, AR Vagadlo, JM Correia De Simas, I Susin. 2001. Adição de probiótico ao leite integral ou sucedáneo e desempenho de bezerros da raça holandesa. Scientia Agricola 58, 215-221.

Oyofo BA, JR DeLoach, DE Corrier, JO Norman, RL Ziprin, HH Mollenhauer. 1989. Effects of carbohydrates on Salmonella Thyphimorium colonization in broilers chickens. Avian diseases 33, $531-534$.

Ozawa K, K Yabu-Uchi, K Yamanaka, Y Yamashita, S Nomura, I Oku. 1983. Effect of Streptococcus faecalis BIO-4R on intestinal flora of weanling piglets and calves. Int J Food Microbiol 45, 1513-1518.

Paulin SM, PR Watson, AR Benmore, M.P Stevens, PW Jones, B Villarreal-Ramos, TS Wallis. 2002. Analysis of Salmonella enterica Serotype-Host Specificity in calves: avirulence of $S$. enterica Serotype Gallinarum correlates with bacterial dissemination from mesenteric lymph nodes and persistence in vivo. Infect Immun 70, 6788-6797.

Rishi P, KM Swapandeep, B Sushma, S Geeta, T Rupinder. 2009. Protective efficacy probiotic alone or in conjunction with a prebiotic in Salmonella-induced liver damage. FEMS Microbiol Ecol 69, 222-230.
Rosmini MR, GJ Sequeira, I Guerrero-Legarreta, LE Martí, R DallaSantina, L Frizzo, JC Bonazza. 2004. Producción de probióticos para animales de abasto: importancia del uso de la microbiota intestinal indígena. Revista Mexicana de Ingeniería Quimica 3, 181-191.

Sarwari AR, LS Magder, P Levine, AM McNamara, S Knower, GL Armstrong, R Etzel, J Hollingsworth, JG Morris. 2001. Serotype Distribution of Salmonella Isolates from food animals after slaughter differs from that of isolates found in humans. J Infect Dis 183, 1295-1299.

Signorini ML, LP Soto, MV Zbrun, GJ Sequeira, MR Rosmini, LS Frizzo. 2012. Impact of probiotic administration on health and faecal microbiota in young calves: A meta-analysis of randomized controlled trials of lactic acid bacteria. Res Vet Sci 93, 250-258.

Silva DG, PRL Silva, JJ Fagliari. 2010. Hemograma e perfil bioquímico sérico, inclusive hemogasométrico, de bezerros infectados experimentalmente com Salmonella Dublin. Arq Bras Med Vet Zootec 62, 251-257.

Soto LP, LS Frizzo, E Bertozzi, A Diaz, LE Martí, R Dalla Santina, GJ Sequeira, MR Rosmini. 2009. Milk evaluation as growth and cold preservation medium of a probiotic inoculum for young calves. $J$. Anim. Vet. Adv. 8, 1353-1360.

Uyeno Y, Y Sekiguchi, Y Kamagata. 2010. rRNA-based analysis to monitor succession of faecal bacterial communities in Holstein calves. Lett Appl Microbiol 5, 570-577.

Wray C, RH Davies. 2000. Salmonella infections in cattle. In: Wray C, Wray A (eds). Salmonella in domestic animals. CABI Publishing, London, UK, Pp 169-191. 